\title{
Effects of seasonal variations and collection methods on the mineral composition of propolis from Apis mellifera Linnaeus Beehives
}

\author{
E. A. Souza ${ }^{a}$, R. Zaluski ${ }^{a}$, N. Veiga ${ }^{b}$ and R. O. Orsia* \\ ${ }^{a}$ Núcleo de Ensino, Ciência e Tecnologia em Apicultura Racional - NECTAR, Departamento de Produção Animal - \\ FMVZ, Universidade Estadual Paulista - UNESP, Distrito de Rubião Jr., s/n, CEP 18618-000, Botucatu, SP, Brazil

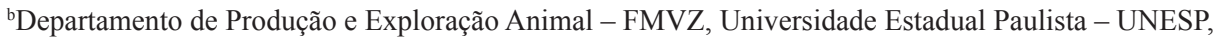 \\ Distrito de Rubião Jr., s/n, CEP 18618-000, Botucatu, SP, Brazil \\ *e-mail: orsi@fmvz.unesp.br
}

Received: August 14, 2014 - Accepted: March 17, 2015 - Distributed: May 31, 2016

\begin{abstract}
The effects of seasonal variations and the methods of collection of propolis produced by Africanized honey bees Apis mellifera Linnaeus, 1758, on the composition of constituent minerals such as magnesium ( $\mathrm{Mg})$, zinc ( $\mathrm{Zn})$, iron ( $\mathrm{Fe})$, sodium $(\mathrm{Na})$, calcium $(\mathrm{Ca})$, copper $(\mathrm{Cu})$, and potassium $(\mathrm{K})$ were evaluated. Propolis was harvested from 25 beehives by scraping or by means of propolis collectors (screen, "intelligent" collector propolis [ICP], lateral opening of the super [LOS], and underlay method). During the one-year study, the propolis produced was harvested each month, ground, homogenized, and stored in a freezer at $-10^{\circ} \mathrm{C}$. Seasonal analyses of the mineral composition were carried out by atomic absorption spectrophotometry and the results were evaluated by analysis of variance (ANOVA), followed by Tukey-Kramer's test to compare the mean values $(\mathrm{p}<0.05)$. The results showed that seasonal variations influence the contents of 5 minerals $(\mathrm{Mg}, \mathrm{Fe}, \mathrm{Na}, \mathrm{Ca}$, and $\mathrm{Cu}$ ), and the propolis harvesting method affects the contents of 4 minerals ( $\mathrm{Mg}, \mathrm{Zn}, \mathrm{Fe}$, and $\mathrm{Ca})$.
\end{abstract}

Keywords: seasonality, macro- and micro-mineral, propolis collectors, spectrophotometry, quality.

\section{Efeitos de variações sazonais e métodos de coleta sobre a composição mineral de própolis de colmeias de Apis mellifera Linnaeus}

\section{Resumo}

A influência da sazonalidade e de métodos de produção de própolis por abelhas africanizadas Apis mellifera Linnaeus, 1758 , sobre a concentração de magnésio $(\mathrm{Mg})$, zinco $(\mathrm{Zn})$, ferro $(\mathrm{Fe})$, sódio $(\mathrm{Na})$, cálcio $(\mathrm{Ca})$, cobre $(\mathrm{Cu})$ e potássio $(\mathrm{K})$ foram avaliados. 25 colmeias foram utilizadas, e a colheita de propolis ocorreu por raspagem ou a partir de coletores (tela, coletor de própolis "inteligente" - CPI, abertura lateral da melgueira - ALM e calço). Durante um ano a própolis foi colhida mensalmente, homogeneizada e armazenada em freezer a $-10^{\circ} \mathrm{C}$. A análise sazonal de minerais foi realizada por espectrofotometria de absorção atômica e os resultados avaliados por análise de variância (ANOVA) seguida do teste de Tukey-Kramer para comparação de médias $(\mathrm{p}<0,05)$. Os resultados demostraram que a sazonalidade afetou o conteúdo de cinco minerais $(\mathrm{Mg}, \mathrm{Fe}, \mathrm{Na}, \mathrm{Ca}$ e $\mathrm{Cu}$ ) e os métodos de coleta afetaram o conteúdo de quatro minerais (Mg, $\mathrm{Zn}, \mathrm{Fe}$ e $\mathrm{Ca})$.

Palavras-chave: sazonalidade, macro e micro-minerais, coletores de própolis, espectrofotometria, qualidade.

\section{Introduction}

Propolis, a gummy and balsamic substance, is a honeybee product obtained from resinous material. It is collected by bees from flowers, buds, and exudates of plants and is known to have a broad spectrum of biological properties (Mello and Hubinger, 2012; Toreti et al., 2013).

The quality and amount of propolis produced are linked to seasonal variations, methods of collection (Inoue et al., 2007; Toreti et al., 2013), geographical diversity, plant sources, and bee species (Mello and Hubinger, 2012).

The method of harvesting may affect the production of propolis in beehives, and depending on the stimulus for resin collection by the collectors, it may add excess beeswax to the propolis, thereby altering its mineral composition.

Propolis is a well-known antioxidant used in the food and drug industry (Simões-Ambrosio et al., 2010; Toreti et al., 2013; Huang et al., 2014). The regional chemical composition of propolis can interfere in its biological properties (Simões-Ambrosio et al., 2010; 
Toreti et al., 2013; Bankova et al., 2014, Souza et al., 2014). The presence of phenolic compounds, steroids, terpenes, and amino acids in propolis has been extensively studied (Sawaya et al., 2011; Finger et al., 2014). Until 2000, over 300 chemical components belonging to the phytochemical classes flavonoids, terpenes, organic acids, and phenolics have been identified in propolis (Huang et al., 2014).

Recently, some researchers investigated the inorganic constituents in propolis and found that its mineral composition varied according to the geographical zone. Korn et al. (2013) evaluated macro- and micro-minerals in natural propolis harvested in Bahia state in the northeast of Brazil, and they found that these propolis samples were not contaminated by potentially toxic species and were a good source of magnesium $(\mathrm{Mg})$, calcium $(\mathrm{Ca})$, potassium (K), and iron (Fe). Finger et al. (2014) studied the concentrations of 11 representative metals in some regions of the Paraná state in South Brazil, and they demonstrated that the concentrations of aluminum (Al), $\mathrm{Ca}$, and $\mathrm{Mg}$ differed in some regions, which could be used to identify not only the geographical origin of propolis, and to identification of specific zones with environmental contamination. Similar studies have been undertaken in other countries such as those by Cantarelli et al. (2011) in Argentina, Gong et al. (2012) in China, and Bonvehí and Bermejo (2013) in Spain.

The human body requires about 20 different minerals in order to function properly. These minerals are indispensable for the maintenance of life, growth, and reproduction (Máhán and Escott-Stump, 2004), and can be classified as macro-or micro-minerals. Macro-minerals such as $\mathrm{Ca}, \mathrm{Mg}$, $\mathrm{K}$, sodium $(\mathrm{Na})$, sulfur $(\mathrm{S})$, chloride $(\mathrm{Cl})$, and phosphorus (P) are needed in amounts higher than $100 \mathrm{mg} /$ day. On the other hand, micro-minerals such as copper $(\mathrm{Cu})$, zinc $(\mathrm{Zn})$, $\mathrm{Fe}$, iodine (I), selenium (Se), and manganese (Mn) are needed in amounts lower than $100 \mathrm{mg} /$ day (Máhán and Escott-Stump, 2004).

Micronutrient deficiencies, which result from a lack of essential vitamins and minerals, are a major public health problem in many countries worldwide. According to the World Health Organization (WHO, 2014), more than two billion people worldwide suffer from one or more micronutrient deficiency.

To our knowledge, no prior study has investigated the mineral composition of propolis produced by different collectors. Because propolis has important applications in the field of medicine (e.g., raw material in drug formulation) and in the food industry (e.g., as a supplement), it is important to determine how local variables such as seasons and methods of collection can influence the composition of propolis, and subsequently affect its biological and nutritional properties. Therefore, the goal of this study was to evaluate the effects of seasonal variations and collection methods on the mineral content of propolis produced by the Africanized Apis mellifera Linnaeus, 1758.

\section{Material and Methods}

The experiment was conducted at the Beekeeping Production Area of Edgárdia Farm, Faculty of Veterinary Medicine and Animal Science, UNESP, Botucatu, São Paulo, Brazil, $22^{\circ} 82^{\prime} \mathrm{S}$ and $48^{\circ} 39^{\prime} \mathrm{W}$, with a humid subtropical (Cfa) climate and an average elevation of $488 \mathrm{~m}$.

Twenty-five colonies of Africanized A. mellifera, housed in Langstroth hives, were used. The colonies were free of diseases or parasites and each had a naturally mated queen. Colonies were not genetically selected for a specific propolis collection. They were standardized according to the number of brood frames and were randomly distributed and organized to only produce propolis. Each type of collector was used to harvest propolis from 5 colonies, as described below:

1. Scraping: Harvest was performed with a chisel, scraping inside the hive, frames, and lid.

2. Screen: A plastic screen with $2 \mathrm{~mm}$ spacing was used under the lid of the hive.

3. Intelligent Collector Propolis (ICP): Adapted supers with mobile side battens $(2 \mathrm{~cm})$, were placed between the lid and the nest of the beehive. Battens from each side were removed every week to stimulate propolis production.

4. Lateral Opening of Supers (LOS): Adapted supers with lateral opening of dimensions $16 \mathrm{~cm} \times$ $8 \mathrm{~cm}$, sealed with translucent and flexible plastic to prevent changes in the nest thermoregulation, but allowing the entrance of luminosity, were used.

5. Underlay: Wooden block, $2 \mathrm{~cm}$ high, was placed between the lid and the nest of the beehive to form an opening for the bees to deposit propolis.

Every month, the propolis produced using each type of collector was harvested, ground, homogenized, and stored in a freezer at $-10^{\circ} \mathrm{C}$. The experiment was conducted from August 2010 to August 2011. The analyses for $\mathrm{Mg}, \mathrm{Zn}$, $\mathrm{Fe}, \mathrm{Na}, \mathrm{Ca}, \mathrm{Cu}$, and $\mathrm{K}$ were performed at the Agricultural and Environmental Laboratory (Agrilab), in Botucatu, São Paulo, Brazil.

Qualitative and quantitative analyses of minerals were performed by atomic absorption spectrometry, following the methodology described by Sarruge and Haag (1974). A Varian model 12/1475 Spectro was used to determine concentrations of $\mathrm{Mg}, \mathrm{Zn}, \mathrm{Fe}, \mathrm{Na}, \mathrm{Ca}, \mathrm{Cu}$, and $\mathrm{K}$. The detection limits for these minerals were set at $0.03,0.04,0.01,0.05$, $0.10,0.07$, and $0.02 \mathrm{ppm}$, respectively. Further, $1 \mathrm{~g}$ of each propolis sample was weighed in pyrex-type tubes and nitropercloric acid solution was added (6:1 nitric acid: perchloride acid) to each tube.

Samples were placed in thermostatically laminar flow block digester (Tecnal, type TE-040/25) and heated to $250{ }^{\circ} \mathrm{C}$ for 2.5 hours to digest and eliminate organic materials. The samples were then suspended in distilled 
water and the volume was made up to $25 \mathrm{~mL}$, before spectrophotometric measurements were performed.

Before the first sample reading, the pattern solutions for each analyzed metal were used to calibrate the equipment. The results were expressed in $\mathrm{mg} \mathrm{kg}^{-1}$. The following Formula 1 was used to calculate the metal quantity in propolis:

$\begin{gathered}\text { Metal concentration } \\ (\mathrm{mg} / \mathrm{kg})\end{gathered}=\frac{\begin{array}{c}\text { (reading metal }- \text { white reading }) \times \\ \text { dilution volume }(25 \mathrm{~mL})\end{array}}{\text { sample weight }(1 \mathrm{~g})}$

The mineral concentration was evaluated by analysis of variance (ANOVA), followed by Tukey-Kramer's test, to verify differences between mean values. They were considered statistically different when $\mathrm{p}<0.05$ (Zar, 2010).

\section{Results}

The macro-mineral content $(\mathrm{Ca}, \mathrm{Mg}, \mathrm{K}$, and $\mathrm{Na}$ ) present in propolis samples estimated based on the location (Botucatu region), season, and the method of propolis collection are presented in Table 1.

The $\mathrm{Ca}$ content in the propolis collected using the scraping was higher during summer and winter $(3985.9 \pm 663.2 \mathrm{mg} / \mathrm{kg}$ and $2066.7 \pm 563.0 \mathrm{mg} / \mathrm{kg}$, respectively) than during autumn $(1423.8 \pm 989.9 \mathrm{mg} / \mathrm{kg})$. Similarly, the Ca content in the propolis collected using the LOS method was higher during summer and winter $(2526.3 \pm 348.2$ and $2417.2 \pm 624.8 \mathrm{mg} / \mathrm{kg}$, respectively) than during spring and autumn $(889.3 \pm 240.5$ and $1101.8 \pm 615.9 \mathrm{mg} / \mathrm{kg}$, respectively). With regard to the method of collection, the Ca content in propolis collected using ICP was higher $(2420.08 \pm 1614 \mathrm{mg} / \mathrm{kg})$ than that in propolis collected using the plastic screen $(738.3 \pm 366.5 \mathrm{mg} / \mathrm{kg})$, specifically during autumn.

The Mg content in propolis collected using the scraping was higher during summer and winter (1545.5 \pm 613.9 and $1021 \pm 134.5 \mathrm{mg} / \mathrm{kg}$, respectively) than during autumn $(897.9 \pm 605.6 \mathrm{mg} / \mathrm{kg})$. For the underlay method, the $\mathrm{Mg}$ content in propolis collected during spring was higher $(3849.4 \pm 478.8 \mathrm{mg} / \mathrm{kg})$ than that collected during summer, autumn, and winter $(1239.3 \pm 386.4 ; 1220.4 \pm 318.2$ and $1234.4 \pm 154.8 \mathrm{mg} / \mathrm{kg}$, respectively). In relation to the method of collection, the $\mathrm{Mg}$ content in propolis collected by the underlay method was higher $(3849.4 \pm 478.8 \mathrm{mg} / \mathrm{kg})$ than that collected using the LOS method $(415.2 \pm 80.4 \mathrm{mg} / \mathrm{kg})$, specifically during spring.

The K content of propolis did not differ significantly due to seasonal variations and collection methods.

The Na content of propolis collected using the LOS method was higher during autumn and winter $(344.8 \pm 96.8$ and $396.0 \pm 152.2 \mathrm{mg} / \mathrm{kg}$, respectively) than during spring and summer $(32.4 \pm 5.1$ and $71.8 \pm 5.2 \mathrm{mg} / \mathrm{kg}$, respectively). Similarly, the Na content in the propolis collected using underlay method was higher during summer, autumn, and winter $(196.2 \pm 103.3 ; 302.7 \pm 114.6$ and $387.8 \pm 206.3 \mathrm{mg} / \mathrm{kg}$, respectively) than during spring $(61.7 \pm 13.7 \mathrm{mg} / \mathrm{kg})$.

The content of micro-minerals $(\mathrm{Cu}, \mathrm{Zn}$, and $\mathrm{Fe})$ present in the propolis samples obtained based on the location (Botucatu region), season, and method of collection are presented in Table 2.

The $\mathrm{Cu}$ content in propolis produced using the scraping was higher during summer and winter (12.24 \pm 1.4 and $11.5 \pm 2.6 \mathrm{mg} / \mathrm{kg}$, respectively) than during spring and autumn ( $4.3 \pm 0.3$ and $4.2 \pm 0.4 \mathrm{mg} / \mathrm{kg}$, respectively).

Table 1. Averages and standard deviation of macro-mineral contents $(\mathrm{Ca}, \mathrm{Mg}, \mathrm{K}$, and $\mathrm{Na})\left(\mathrm{mg} / \mathrm{kg}^{-1}\right)$ found in propolis according to seasonality and production method (Scraping, Screen, "Intelligent" Collector Propolis [ICP], Lateral Opening of the Super [LOS], and Underlay) in Botucatu, São Paulo, Brazil.

\begin{tabular}{ccccccc}
\hline $\begin{array}{c}\text { Mineral } \\
(\mathbf{m g} / \mathbf{k g})\end{array}$ & Season & Scraping & Screen & ICP & LOS & Underlay \\
\hline & Spring & $2187.2 \pm 1430.9 \mathrm{ABa}$ & $1274.9 \pm 634.3 \mathrm{Aa}$ & $1994.9 \pm 808.7 \mathrm{Aa}$ & $889.3 \pm 240.5 \mathrm{Ba}$ & $2261.4 \pm 661.8 \mathrm{Aa}$ \\
Calcium & Summer & $3985.9 \pm 663.2 \mathrm{Aa}$ & $2360.7 \pm 1062.2 \mathrm{Aa}$ & $3292.1 \pm 735.7 \mathrm{Aa}$ & $2526.3 \pm 348.2 \mathrm{Aa}$ & $3112.2 \pm 812.0 \mathrm{Aa}$ \\
$(\mathrm{Ca})$ & Autumn & $1423.8 \pm 989.9 \mathrm{Bab}$ & $738.3 \pm 366.5 \mathrm{Ab}$ & $2420.08 \pm 1614.1 \mathrm{Aa}$ & $1101.8 \pm 615.9 \mathrm{Bab}$ & $2291.7 \pm 1301.4 \mathrm{Aab}$ \\
& Winter & $2066.7 \pm 563.0 \mathrm{Aa}$ & $1808.7 \pm 548.9 \mathrm{Aa}$ & $2675.33 \pm 695.16 \mathrm{Aa}$ & $2417.2 \pm 624.8 \mathrm{Aa}$ & $2286.3 \pm 177.3 \mathrm{Aa}$ \\
\hline & Spring & $1303.2 \pm 1382.0 \mathrm{ABab}$ & $1001.4 \pm 983.3 \mathrm{Aab}$ & $1682.3 \pm 1322.5 \mathrm{Aab}$ & $415.2 \pm 80.4 \mathrm{Ab}$ & $3849.4 \pm 478.8 \mathrm{Aa}$ \\
Magnesium & Summer & $1545.5 \pm 613.9 \mathrm{Aa}$ & $1076.9 \pm 366.6 \mathrm{Aa}$ & $1831.9 \pm 550.2 \mathrm{Aa}$ & $2166.7 \pm 1251.4 \mathrm{Aa}$ & $1239.3 \pm 386.4 \mathrm{Ba}$ \\
$(\mathrm{Mg})$ & Autumn & $897.9 \pm 605.6 \mathrm{Ba}$ & $698.5 \pm 175.4 \mathrm{Aa}$ & $5665.1 \pm 7366.7 \mathrm{Aa}$ & $749.6 \pm 164.5 \mathrm{Aa}$ & $1220.4 \pm 318.2 \mathrm{Ba}$ \\
& Winter & $1021.3 \pm 134.5 \mathrm{Aa}$ & $1210.2 \pm 561.6 \mathrm{Aa}$ & $1362 \pm 145.1 \mathrm{Aa}$ & $1157.5 \pm 261.2 \mathrm{Aa}$ & $1234.4 \pm 154.8 \mathrm{Ba}$ \\
\hline & Spring & $2546.9 \pm 1092.9 \mathrm{Aa}$ & $2065.3 \pm 235.9 \mathrm{Aa}$ & $1809.9 \pm 398.4 \mathrm{Aa}$ & $1904.3 \pm 140.5 \mathrm{Aa}$ & $2777.9 \pm 687.4 \mathrm{Aa}$ \\
Potassium & Summer & $1809.9 \pm 398.4 \mathrm{Aa}$ & $6230.9 \pm 1643.7 \mathrm{Aa}$ & $6726.3 \pm 3682.1 \mathrm{Aa}$ & $2804.8 \pm 487.0 \mathrm{Aa}$ & $4124.2 \pm 1851.4 \mathrm{Aa}$ \\
$(\mathrm{K})$ & Autumn & $5321.5 \pm 3171.7 \mathrm{Aa}$ & $4254.6 \pm 2903.1 \mathrm{Aa}$ & $6027.8 \pm 3606.3 \mathrm{Aa}$ & $2026.9 \pm 241.1 \mathrm{Aa}$ & $4623.7 \pm 358.2 \mathrm{Aa}$ \\
& Winter & $4136.4 \pm 657.9 \mathrm{Aa}$ & $4908.7 \pm 2816.0 \mathrm{Aa}$ & $4677.6 \pm 1451.8 \mathrm{Aa}$ & $3149.8 \pm 2008.2 \mathrm{Aa}$ & $4148.5 \pm 870.2 \mathrm{Aa}$ \\
\hline & Spring & $69.0 \pm 32.1 \mathrm{Aa}$ & $66.2 \pm 24.9 \mathrm{Aa}$ & $35.5 \pm 11.7 \mathrm{Aa}$ & $32.4 \pm 5.1 \mathrm{Ba}$ & $61.7 \pm 13.7 \mathrm{Ba}$ \\
Sodium & Summer & $245.0 \pm 225.4 \mathrm{Aa}$ & $186.2 \pm 100.6 \mathrm{Aa}$ & $194.9 \pm 120.3 \mathrm{Aa}$ & $71.8 \pm 5.2 \mathrm{Ba}$ & $196.2 \pm 103.3 \mathrm{Aa}$ \\
$(\mathrm{Na})$ & Autumn & $197.3 \pm 132.6 \mathrm{Aa}$ & $220.4 \pm 153.8 \mathrm{Aa}$ & $293.2 \pm 141.4 \mathrm{Aa}$ & $344.8 \pm 96.8 \mathrm{Aa}$ & $302.7 \pm 114.6 \mathrm{Aa}$ \\
& Winter & $404.1 \pm 148.3 \mathrm{Aa}$ & $351.7 \pm 159.6 \mathrm{Aa}$ & $284.0 \pm 171.8 \mathrm{Aa}$ & $396.0 \pm 152.2 \mathrm{Aa}$ & $387.8 \pm 206.3 \mathrm{Aa}$
\end{tabular}

Averages followed by the same uppercase letter followed by the same capital letter in the column do not differ from each other according to Tukey's Test $(\mathrm{p}<0.05)$. Averages followed by the same small letter in the row do not differ from each other according to Tukey's Test $(\mathrm{p}<0.05)$. 
Table 2. Averages and standard deviation of micro-mineral contents $(\mathrm{Cu}, \mathrm{Zn}$ and $\mathrm{Fe})\left(\mathrm{mg} / \mathrm{kg}^{-1}\right)$ found in propolis according to seasonality and production method (Scraping, Screen, "Intelligent" Collector Propolis [ICP], Lateral Opening of the Super [LOS], and Underlay) in Botucatu, São Paulo, Brazil.

\begin{tabular}{|c|c|c|c|c|c|c|}
\hline \multirow{2}{*}{$\begin{array}{r}\text { Mineral } \\
\left(\mathrm{mg} \mathrm{kg}^{-1}\right)\end{array}$} & \multirow{2}{*}{ Season } & \multicolumn{5}{|c|}{ Collection Method } \\
\hline & & Scraping & Screen & ICP & LOS & Underlay \\
\hline \multirow{4}{*}{$\begin{array}{c}\text { Copper } \\
(\mathrm{Cu})\end{array}$} & Spring & $4.3 \pm 0.3 \mathrm{Ba}$ & $4.8 \pm 2.0 \mathrm{Aa}$ & $2.7 \pm 0.6 \mathrm{Aa}$ & $5.3 \pm 0.8 \mathrm{Aa}$ & $6.5 \pm 3.7 \mathrm{Aa}$ \\
\hline & Summer & $12.24 \pm 1.4 \mathrm{Aa}$ & $9.4 \pm 7.0 \mathrm{Aa}$ & $8.0 \pm 6.7 \mathrm{Aa}$ & $5.7 \pm 0.7 \mathrm{Aa}$ & $7.5 \pm 6.3 \mathrm{Aa}$ \\
\hline & Autumn & $4.2 \pm 0.4 \mathrm{Ba}$ & $3.2 \pm 3.1 \mathrm{Aa}$ & $4.6 \pm 1.8 \mathrm{Aa}$ & $6.1 \pm 3.1 \mathrm{Aa}$ & $6.2 \pm 1.1 \mathrm{Aa}$ \\
\hline & Winter & $11.5 \pm 2.6 \mathrm{Aa}$ & $12.4 \pm 2.3 \mathrm{Aa}$ & $6.9 \pm 6.9 \mathrm{Aa}$ & $11.0 \pm 3.4 \mathrm{Aa}$ & $11.8 \pm 1.7 \mathrm{Aa}$ \\
\hline \multirow{4}{*}{$\begin{array}{l}\text { Zinc } \\
(\mathrm{Zn})\end{array}$} & Spring & $113.5 \pm 16.9 \mathrm{Aa}$ & $145.7 \pm 43.3 \mathrm{Aa}$ & $91.1 \pm 7.5 \mathrm{Aa}$ & $131.8 \pm 22.4 \mathrm{Aa}$ & $85.3 \pm 11.6 \mathrm{Aa}$ \\
\hline & Summer & $68.2 \pm 55.2 \mathrm{Aa}$ & $55.2 \pm 15.6 \mathrm{Aa}$ & $55.7 \pm 20.4 \mathrm{Aa}$ & $101.0 \pm 3.8 \mathrm{Aa}$ & $45.5 \pm 23.4 \mathrm{Aa}$ \\
\hline & Autumn & $30.8 \pm 19.8 \mathrm{Ab}$ & $49.3 \pm 13.7 \mathrm{Aab}$ & $87.1 \pm 43.3 \mathrm{Aa}$ & $79.9 \pm 43.8 \mathrm{Aab}$ & $44.3 \pm 9.9 \mathrm{Aab}$ \\
\hline & Winter & $74.64 \pm 15.2 \mathrm{Aa}$ & $66.5 \pm 10.6 \mathrm{Aa}$ & $95.9 \pm 41.1 \mathrm{Aa}$ & $64.0 \pm 3.2 \mathrm{Aa}$ & $63.3 \pm 18.8 \mathrm{Aa}$ \\
\hline \multirow{4}{*}{$\begin{array}{l}\text { Iron } \\
(\mathrm{Fe})\end{array}$} & Spring & $459.5 \pm 272.0 \mathrm{Aa}$ & $273.9 \pm 125.6 \mathrm{Aa}$ & $242.1 \pm 109.4 \mathrm{Aa}$ & $179.7 \pm 67.6 \mathrm{ABa}$ & $528.6 \pm 63.5 \mathrm{Aa}$ \\
\hline & Summer & $228.9 \pm 46.2 \mathrm{Aa}$ & $176.1 \pm 36.9 \mathrm{Aa}$ & $278.6 \pm 262.4 \mathrm{Aa}$ & $413.0 \pm 96.4 \mathrm{Aa}$ & $246.7 \pm 121.3 \mathrm{Ba}$ \\
\hline & Autumn & $156.2 \pm 88.3 \mathrm{Aa}$ & $92.3 \pm 35.3 \mathrm{Aa}$ & $172.1 \pm 53.5 \mathrm{Aa}$ & $57.7 \pm 49.8 \mathrm{Ba}$ & $181.0 \pm 35.7 \mathrm{Ba}$ \\
\hline & Winter & $325.6 \pm 122.2 \mathrm{Aab}$ & $131.5 \pm 51.4 \mathrm{Ab}$ & $397.6 \pm 132.1 \mathrm{Aa}$ & $343.8 \pm 141.2 \mathrm{Aab}$ & $391.4 \pm 26.5 \mathrm{ABa}$ \\
\hline
\end{tabular}

Averages followed by the same capital letter in the column do not differ from each other according to Tukey's Test ( $\mathrm{p}<0.05)$. Averages followed by the same small letter in the row do not differ from each other according to Tukey's Test $(\mathrm{p}<0.05)$.

In the case of $\mathrm{Zn}$, seasonal variation did not alter the mineral content in propolis. Based on the collection method used, the $\mathrm{Zn}$ content in the propolis collected using ICP was higher $(87.43 \pm 43.3 \mathrm{mg} / \mathrm{kg})$ than that collected using the scraping $(30.8 \pm 19.8 \mathrm{mg} / \mathrm{kg})$, specifically in autumn.

The Fe content in propolis collected using the LOS method was higher during summer and winter $(413.0 \pm 96.4$ and $343.8 \pm 141.2 \mathrm{mg} / \mathrm{kg}$, respectively) than during autumn $(57.7 \pm 49.8 \mathrm{mg} / \mathrm{kg})$. The Fe content in propolis collected using the underlay method was higher during spring $(528.6 \pm 63.5 \mathrm{mg} / \mathrm{kg})$ than during summer and autumn $(246.7 \pm 121.3$ and $181.0 \pm 35.7 \mathrm{mg} / \mathrm{kg}$, respectively). In relation to the method of collection, the Fe content in propolis collected using the ICP method was higher $(397.6 \pm 132.1 \mathrm{mg} / \mathrm{kg})$ than that collected using the screen method $(131.5 \pm 51.4 \mathrm{mg} / \mathrm{kg})$, specifically during winter.

\section{Discussion}

The results of this study show that the season of propolis harvest and the method used can interfere with the mineral content composition of this bee product. It is important to note that the bees in this study were located in the same place and collected resins in the same area; therefore, they were exposed to the same soil and climatic conditions. However, bees collect resins from different plant sources throughout the year and the collection method can influence the collection of resin, which could explain the seasonal differences in the mineral content of propolis. Bastos et al. (2011) have demonstrated that some plants produce more resins in certain periods. For example, in rainy seasons, it is observed that $A$. mellifera bees and other insects show an increased attraction to plants, resulting in collection of greater amounts of resin (Bastos et al., 2011).

The contents of macro- and micro-minerals in the soil can also differ based on the geographical region (Espinoza et al., 1991; Alloway, 2013), thus influencing the type of minerals available to plants. Specific plants can produce resins with different mineral content. According to Raven and Johnson (2002), the absorption of nutrients in the soil varies according to the requirements of each plant species, their development, and climate conditions. Furthermore, pollen content in propolis could interfere with the study results, as pollen represents approximately $5 \%$ of the final composition of propolis (Huang et al., 2014). The pollen present in propolis may vary according to the botanical origin (Freitas et al., 2011), and the minerals in pollen are affected by geographic and seasonal variations (Morgano et al., 2012) as well. Collectively, these factors can influence the mineral composition of propolis. Therefore, possible differences in the resin collected, due to plant diversity or preference of bees to a certain plant species during a specific season, could explain the results obtained herein.

The mineral composition of propolis has also found to vary according to the collection method, which may be attributable to the wax content. Conditions of resin scarcity and the stimulus the bees receive from the propolis collectors can cause them to add an excess amount of wax to the propolis produced, thereby interfering with the mineral content. Silva et al. (2006) have shown that periods of resin scarcity (that overlap with periods of low precipitation) contribute to the increased wax content in propolis.

Korn et al. (2013) reported that propolis from the Bahia state is a good source of $\mathrm{Ca}, \mathrm{K}, \mathrm{Mg}$, and $\mathrm{Fe}$; however, comparison of the mean values obtained in the present study showed that the contents of these elements and of $\mathrm{Na}$ and $\mathrm{Cu}$ were higher, whereas that of $\mathrm{Zn}$ was within the reported range. Comparison of the mean values obtained in this study to those previously recorded in the Paraná state (Finger et al., 2014) showed that $\mathrm{Ca}$ and $\mathrm{Mg}$ concentrations were within the reported range, $\mathrm{Zn}$ concentration was 
higher, and $\mathrm{K}$ and $\mathrm{Na}$ concentrations were lower. These comparisons show that propolis from different Brazilian areas have different mineral composition and that propolis from the Botucatu region is a good source of $\mathrm{Ca}, \mathrm{K}, \mathrm{Mg}$, $\mathrm{Zn}, \mathrm{Fe}, \mathrm{Na}$ and $\mathrm{Cu}$.

Comparison of the mean values of mineral concentrations in propolis recorded in the present study with those recorded by Gong et al. (2012) showed that $\mathrm{Ca}$ concentrations were within the reported range; however, $\mathrm{Mg}$ and $\mathrm{K}$ concentrations were higher, whereas $\mathrm{Na}, \mathrm{Zn}$, and Fe concentrations were lower. Compared to propolis produced in South Spain (Bonvehí and Bermejo, 2013), the concentrations of $\mathrm{Ca}$, $\mathrm{Na}$, and $\mathrm{Fe}$ reported in our study were very similar and those of $\mathrm{Mg}, \mathrm{K}$, and $\mathrm{Cu}$ were within the reported range. However, $\mathrm{Zn}$ concentrations were relatively low.

Macro- and micro-minerals are important for maintaining good health (Máhán and Escott-Stump, 2004; Alsafwah et al., 2007). Owing to the significance of propolis in the food and drug industry, this study demonstrates that it is important know the origin, period, and method of propolis collection, as these factors can influence the mineral composition of propolis.

\section{Conclusion}

The evaluation of the mineral composition of propolis contributes to the understanding of its quality and shows that not only seasonal variations but also the collection method influences the mineral contents present in the propolis produced. On the basis of the results of this study, we can conclude that the propolis collection method affects the concentration of macro-mineral $\mathrm{Ca}$ and $\mathrm{Mg}$; and of micro-mineral $\mathrm{Zn}$ and $\mathrm{Fe}$; whereas seasonal variations affect the concentration of macro-mineral $\mathrm{Ca}, \mathrm{Mg}$, and $\mathrm{Na}$; and of micro-minerals $\mathrm{Fe}$ and $\mathrm{Cu}$.

\section{Acknowledgements}

To the CNPq - Conselho Nacional de Desenvolvimento Científico e Tecnológico for the scholarship granted to the first author.

\section{References}

ALLOWAY, B.J., 2013. Bioavailability of elements in soil. In: O. SELINUS, ed. Essential of medical geology. Netherlands: Springer. 805 p. http://dx.doi.org/10.1007/978-94-007-4375-5_15.

ALSAFWAH, S., LAGUARDIA, S.P., ARROYO, M., DOCKERY, B.K., BHATTACHARYA, S.K., AHOKAS, R.A. and NEWMAN, K.P., 2007. Congestive heart failure is a systemic illness: a role for minerals and micronutrients. Clinical Medicine \& Research, vol. 5, no. 4, pp. 238-243. http://dx.doi.org/10.3121/cmr.2007.737. PMid:18367709.

BANKOVA, V., GALABOV, A.S., ANTONOVA, D., VILHELMOVA, N. and DI PERRI, B., 2014. Chemical composition of propolis extract $\mathrm{ACF}^{\circledR}$ and activity against herpes simplex virus. Phytomedicine, vol. 21, no. 11, pp. 1432-1438. http://dx.doi.org/10.1016/j. phymed.2014.04.026. PMid:25022206.
BASTOS, E.M.A.F., SANTANA, R.A., CALACA-COSTA, A.G.F. and THIAGO, P.S., 2011. Interaction between Apis mellifera L. and Baccharis dracunculifolia DC, that favours green propolis production in Minas Gerais. Brazilian Journal of Biology = Revista Brasileira de Biologia, vol. 71, no. 3, pp. 727-734. http:// dx.doi.org/10.1590/S1519-69842011000400018. PMid:21881797.

BONVEHÍ, J.S. and BERMEJO, F.J., 2013. Element content of propolis collected from different areas of South Spain. Environmental Monitoring and Assessment, vol. 185, no. 7, pp. 6035-6047. http://dx.doi.org/10.1007/s10661-012-3004-3. PMid:23188070.

CANTARELLI, M.A., CAMINA, J.M., PETTENATI, E.M., MARCHEVSKY, E.J. and PELLERANO, R.G., 2011. Trace mineral content of Argentinean raw propolis by neutron activation analysis (NAA): Assessment of geographical provenance by chemometrics. LWT -. Food Science and Technology (Campinas.), vol. 44, no. 1, pp. 256-260. http://dx.doi.org/10.1016/j.lwt.2010.06.031.

ESPINOZA, J.E., MCDOWELL, L.R., WILKINSON, N.S., CONRAD, J.H. and MARTIN, F.G., 1991. Monthly variation of forage and soil minerals in central Florida II. Trace minerals. Communications in Soil Science and Plant Analysis, vol. 22, no. 1112, pp. 1137-1149. http://dx.doi.org/10.1080/00103629109368480.

FINGER, D., KELTE FILHO, I.K., TORRES, Y.R. and QUINA'IA, S.P., 2014. Propolis as an indicator of environmental contamination by metals. Bulletin of Environmental Contamination and Toxicology, vol. 92, no. 3, pp. 259-264. http://dx.doi.org/10.1007/s00128014-1199-4. PMid:24414164.

FREITAS, A.S., BARTH, O.M., SALES, E.O., MATSUDA, A.H. and ALMEIDA-MURADIAN, L.B., 2011. A palynological analysis of Brazilian propolis samples. Journal of ApiProduct and ApiMedical Science, vol. 3, no. 2, pp. 67-74. http://dx.doi. org/10.3896/IBRA.4.03.2.01.

GONG, S., LUO, L., GONG, W., GAO, Y. and XIE, M., 2012. Multivariate analyses of element concentrations revealed the groupings of propolis from different regions in China. Food Chemistry, vol. 134, no. 1, pp. 583-588. http://dx.doi.org/10.1016/j. foodchem.2012.02.127.

HUANG, S., ZHANG, C.-P., WANG, K., LI, G.Q. and HU, F.-L., 2014. Recent advances in the chemical composition of propolis. Molecules (Basel, Switzerland), vol. 19, no. 12, pp. 19610-19632. http://dx.doi.org/10.3390/molecules191219610. PMid:25432012.

INOUE, H.T., SOUSA, E.A., ORSI, R.O., FUNARI, S.R.C., BARRETO, L.M.R.C. and DIB, A.P.D.S., 2007. Produção de própolis por diferentes métodos de coleta. Archivos Latinoamericanos de Producción Animal, vol. 15, no. 2, pp. 65-69.

KORN, M.G.A., GUIDA, M.A.B., BARBOSA, J.T.P., TORRES, E.A., FERNANDES, A.P., SANTOS, J.C.C., DANTAS, K.G.F. and NÓBREGA, J.A., 2013. Evaluation of sample preparation procedures for trace element determination in Brazilian propolis by inductively coupled plasma optical emission spectrometry and their discrimination according to geographic origin. Food Analytical Methods, vol. 6, no. 3, pp. 872-880. http://dx.doi. org/10.1007/s12161-012-9497-0.

MÁHÁN, K.L. and ESCOTT-STUMP, S., 2004. Krause's food, nutrition \& diet therapy. Philadelphia: Saunders. $1321 \mathrm{p}$.

MELLO, B.C.B.S. and HUBINGER, M.D., 2012. Antioxidant activity and polyphenol contents in Brazilian green propolis extracts prepared with the use of ethanol and water as solvents in different $\mathrm{pH}$ values. International Journal of Food Science \& Technology, vol. 47, no. 12, pp. 2510-2518. http://dx.doi. org/10.1111/j.1365-2621.2012.03129.x. 
MORGANO, M.A., MARTINS, M.C.T., RABONATO, L.C., MILANI, R.F., YOTSUYANAGI, K. and RODRIGUEZ-AMAYA, D.B., 2012. A comprehensive investigation of the mineral composition of Brazilian bee pollen: geographic and seasonal variations and contribution to human diet. Journal of the Brazilian Chemical Society, vol. 23, no. 4, pp. 727-736. http://dx.doi.org/10.1590/ S0103-50532012000400019.

RAVEN, P.H. and JOHNSON, G.B., 2002. Biology. 6th ed. Boston: McGraw-Hill.

SARRUGE, J.R. and HAAG, H.P., 1974. Análises químicas em plantas. Piracicaba: Esalq/USP. 56 p.

SAWAYA, A.C.H.F., BARBOSA DA SILVA CUNHA, I. and MARCUCCI, M.C., 2011. Analytical methods applied to diverse types of Brazilian propolis. Chemistry Central Journal, vol. 5, no. 27, pp. 1-10. http://dx.doi.org/10.1186/1752-153X-5-27. PMid:21631940.

SILVA, R.A., RODRIGUES, A.E., RIBEIRO, M.C.M., CUSTÓDIO, A.R., ANDRADE, N.E.D. and PEREIRA, W.E., 2006. Características físico-químicas e atividade antimicrobiana de extratos de própolis da Paraíba, Brasil. Ciência Rural, vol. 36, no. 6, pp. 1842-1848. http://dx.doi.org/10.1590/S0103-84782006000600027.
SIMÕES-AMBROSIO, L.M.C., GREGÓRIO, L.E., SOUSA, J.P.B., FIGUEIREDO-RINHEL, A.S.G., AZZOLINI, A.E.C.S., BASTOS, J.K. and LUCISANO-VALIM, Y.M., 2010. The role of seasonality on the inhibitory effect of Brazilian green propolis on the oxidative metabolism of neutrophils. Fitoterapia, vol. 81, no. 8, pp. 1102-1108. http://dx.doi.org/10.1016/j.fitote.2010.07.008. PMid:20637843.

SOUZA, E.A., INOUE, H.T., ARY, F.J., VEIGA, N., ORSI, R.O., 2014. Influence of seasonality and production method on the antibacterial activity of propolis. Acta Scientiarum. Animal Science, vol. 36, no. 1, pp. 49-53. http://dx.doi.org/10.4025/ actascianimsci.v36i1.21436.

TORETI, V.C., SATO, H.H., PASTORE, G.M. and PARK, Y.K., 2013. Recent progress of propolis for its biological and chemical compositions and its botanical origin. Evidence-Based Complementary and Alternative Medicine, vol. 2013, 697390, pp. 1-13. http://dx.doi.org/10.1155/2013/697390.

WORLD HEALTH ORGANIZATION - WHO, 2014 [viewed 16 March 2015]. Countries vow to combat malnutrition through firm policies and actions [online]. Available from:http://www.who.int/ mediacentre/news/releases/2014/icn2-nutrition/en/

ZAR, J.H., 2010. Biostatistical Analysis. New Jersey: Pearson Prentice Hall. 944 p. 